\title{
KEPUASAAN MAHASISWA TERHADAP PEMBELAJARAN DARING SELAMA PANDEMI COVID-19
}

\author{
Maria Theresia Priyastuti*, Suhadi \\ STIKes St. Elisabeth Semarang, Jln. Kawi No. 11 Semarang, Jawa Tengah, Indonesia 50232 \\ *priyastuti.maria@gmail.com
}

\begin{abstract}
ABSTRAK
Penelitian ini membahas tentang tingkat kepuasaan mahasiswa terhadap pembelajaran daring selama masa pandemi covid19 di Stikes St. Elisabeth. Tujuan dari penelitian ini adalah untuk mengetahui tingkat kepuasan mahasiswa terhadap pembelajaran daring selama masa pandemi covid-19 di Stikes St. Elisabeth. Metode penelitian ini menggunakan dekriptif kuantitatif. Pengambilan data dilakukan melalui penyebaran angket/kuesioner secara online. Jumlah sampel adalah 55 mahasiswa prodi Diploma Keperawatan Stikes St. Elisabeth saat semester ganjil 2020/2021. Teknik sampel mengambil total sampling dengan analisis univariat menggunakan distribusi frekuensi. Hasil penelitian adalah mahasiswa merasa puas terhadap peran dosen dalam membantu mahasiswa saat perkuliahan daring $(63.6 \%)$ dan evaluasi pembelajaran daring (56.4\%). Kesimpulan dari penelitian ini adalah sebagian besar mahasiswa merasa kurang puas terhadap pembelajaran daring yang dilakukan di Stikes St. Elisabeth Semarang.
\end{abstract}

Kata Kunci: covid-19; kepuasan; mahasiswa; pembelajaran daring

\section{ABSTRACT}

This research discusses the level of student's satisfaction towards online learning during the Covid-19 pandemic in Stikes St. Elisabeth. The purpose of this research is to determine the level of student's satisfaction towards online learning during the Covid-19 pandemic in Stikes St. Elisabeth. The method for this research was descriptive quantitative. Data was collected by distributing online questionnaires. The total samples of the data were 55 Nursing students of Diploma study program in Stikes St. Elisabeth during the odd semester of 2020/2021. The sampling techniques took total sampling with univariat analysis using frequency distribution. The results showed that the role of lecturers in helping students during online lecturing (63.6\%) and evaluation of online learning (56.4\%). The conclusion of this research is that most students feel less satisfied with online learning conducted in Stikes St. Elisabeth Semarang.

Keywords: Covid-19; online learning; satisfaction; student

\section{PENDAHULUAN}

Pandemi merupakan suatu kondisi dimana suatu wilayah luas terjangkiti wabah penyakit yang menular dan dapat menyebabkan kematian secara serempak. Dengan kata lain pandemi merupakan situasi yang memungkinkan populasi seluruh dunia akan terkena infeksi dan menyebabkan sakit. Menurut WHO, pandemi merupakan penyebaran penyakit berskala global yang terjadi di seluruh dunia. Covid-19 merupakan salah satu jenis virus yang dapat menularkan ke semua orang, mulai dari bayi sampai lansia (https://dikpora.bantulkab.go.id). Virus corona menyerang pada sistem pernapasan, mulai dari gejala ringan sampai dengan gejala berat, bahkan dapat berakibat fatal yaitu kematian.

Saat ini virus corona-19 telah menjadi pandemi dunia dan menyebar secara luas ke berbagai negara di seluruh dunia., seperti yang dinyatakan oleh WHO. Upaya pencegahan terhadap penyebaran covid-19 telah dilakukan di banyak negara dengan melakukan kebijakan lockdown. Meskipun Indonesia sebagai salah satu negara yang terdampak pandemi covid-19, Indonesia tidak memberlakukan kebijakan lockdown, tetapi kebijakan Pembatasan Sosial Berskala Besar (PSBB) dalam rangka menekan laju penyebaran covid-19 (https://bdkjakarta.kemenag.go.id). Kebijakan PSBB sebagai peraturan kedaruratan kesehatan masyarakat yang diberlakukan pemerintah, tertuang dalam Undang-Undang Kekarantinaan Kesehatan Pasal 59 Ayat 2 pada tahun 2020. Di dalam UndangUndang Kekarantinaan Kesehatan, pasal 59 Ayat 3 tahun 2020 dijelaskan bahwa PSBB terdiri atas 
pembatasan di beberapa tempat dan kegiatan seperti sekolah dan tempat kerja, kegiatan agama, dan atau kegiatan di tempat umum. Dengan adanya kebijakan PSBB menyebabkan pembatasan di sektor pendidikan.

Salah satu kebijakan yang diambil pemerintah pada sektor pendidikan, yaitu melakukan perubahan pembelajaran dari pembelajaran tatap muka di kelas menjadi pembelajaran online (Fey dalam CNN Indonesia,2020). Kebijakan pemerintah dalam Surat Edaran Kemendikbud Direktorat Pendidikan Tinggi No. 1 Tahun 2020 tentang pencegahan penyebaran Covid-19 di perguruan tinggi dan Surat Sekjen Mendikbud nomor 35492/A.A5/HK/2020 perihal pencegahan penyebaran Covid-19. Suni Astini, (2020) dalam Surat edaran dan himbauan dari masing-masing Pemerintah Daerah domisili Perguruan Tinggi, maka kebijakan pemerintah dan pemerintah daerah memberikan instruksi kepada perguruan tinggi untuk tetap melaksanakan kegiatan pembelajaran melalui pembelajaran jarak jauh. Hal ini dilakukan pemerintah untuk menekan bertambahnya jumlah populasi yang terdampak positif penderita covid 19.

Pembelajaran jarak jauh mengakibatkan dosen maupun mahasiswa harus belajar dari rumah secara daring. Pembelajaran ini membutuhkan koneksi jaringan atau wifi yang disambungkan dengan media smartphone, laptop, atau komputer. Pembelajaran jarak jauh yang telah dilakukan dalam jaringan/internet, memudahkan dosen dan mahasiswa melakukan pembelajaran dari rumah untuk mencegah terjadinya penyebaran covid 19 . Upaya pencegahan tersebut dilakukan dengan mengikuti social distancing dimana dosen mengajar dari rumah dan mahasiswa terpaksa belajar dari rumah saja. Akibat dari social distancting membuat perubahan sistem pembelajaran menjadi daring atau online. Perubahan sistem pembelajaran tersebut memberikan dampak yang berbeda pada mutu pembelajaran mahasiswa (Karwati, 2014).

Pembelajaran daring merupakan pembelajaran yang memanfaatkan internet dan media digital disertai dengan aksesibilitas, konektivitas, fleksibilitas dalam penyampaian materinya, dan kemampuan untuk memunculkan berbagai jenis interaksi pembelajaran (Moore, Dickson-Deane, \& Galyen,2011) Menurut Rizal Fadli (https://www.halodoc.com) pembelajaran online atau daring menjadi trend di era digital dengan produk-produk berteknologi dan alternatif pembelajaran dalam berbagai situasi dengan segala manfaatnya. Pembelajaran daring/online bersifat fleskibel, yang memungkinkan dosen dan mahasiswa dapat mengakses semua informasi dan bahan pembelajaran dengan sangat mudah tanpa terkendala waktu dan batasan ruang. Pembelajaran daring dengan penggunaan virtual learning memberikan kemudahan langsung dalam berkomunikasi sehingga penerimaan materi lebih mudah dipahami (Munawaroh dalam Lestari, 2020).

Gikas \& Grant (2013) berpendapat bahwa untuk melakukan pembelajaran daring diperlukan adanya yang alat-alat pedukung perangkat mobile seperti jaringan internet, telepon genggam (HP)/smartphone, tablet, laptop dan komputer memadai,yang dapat dipergunakan tuk mengakses informasi dimana dan kapan saja. Lebih lanjut Korucu \& Alkan (2011) menyatakan bahwa penggunaan teknologi yang mobile berperan besar dalam pembelajaran, khususnya pencapaian tujuan pembelajaran jarak jauh.

Ada beberapa ciri pembelajaran daring yaitu 1) pembelajaran daring lebih menekankan kepada mahasiswa untuk mengolah informasi yang disajikan oleh dosen secara online, 2) pembelajaran daring sebagai aktivitas pembelajaran terjadi melalui jaringan/Internet, 3) pembelajaran daring diberikan dosen pada mahasiswa secara efektif tanpa memandang latar belakang mahasiswa, 4) pembelajaran daring diberikan dengan cara yang lebih interaktif, dan menarik, 5) pembelajaran daring dapat memfasilitasi mahasiswa untuk mengelola konten, akses informasi, dan bahan ajar secara daring, 6) pembelajaran daring menuntut keaktifan mahasiswa selama proses pembelajaran untuk mampu meningkatkan hasil belajar mahasiswa, 7) pembelajaran daring menuntut dosen untuk memilih media pembelajaran yang sesuai kebutuhan mahasiswa dengan tetap memperhatikan mutu capaian pembelajaran daring. Menurut Hanum (2013) ciri pembelajaran daring adalah 1) tujuan pembelajaran yang relevan dengan konten; 2) metode pembelajaran menggunakan instruksi; 3) penyampaian materi 
pembelajaran menggunakan media; 4) rancangan pembelajaran dipusatkan pada pengajar atau mandiri; 5) tujuan pembelajaran memuat pemahaman dan keterampilan.

Berkaitan dengan instruksi Kemendikbud di atas, pembelajaran bagi mahasiswa Stikes St. Elisabeth juga dilakukan secara daring selama pandemi covid-19. Hal ini dilakukan untuk mencegah terjadinya penyebaran virus covid-19. Pembelajaran daring menggunakan media pembelajaran secara online dengan tetap memperhatikan mutu pembelajaran agar capaian pembelajaran tetap dapat terpenuhi (Prasetya, T.A, \& Harjanto C.T.,2020). Media pembelajaran menjadi perantara komunikasi yang baik bagi dosen dan mahasiswa dalam memberikan bahan ajar sesuai capaian pembelajaran di rencana pembelajaran semester (RPS). Dengan media pembelajaran daring diharapkan dosen dapat memberikan materi dan penugasan secara virtual yang dapat membimbing dan mengarahkan mahasiswa supaya dapat memperoleh pemahaman materi dan hasil penilaian pembelajaran secara maksimal. Berbagai media pembelajaran daring telah digunakan dosen Stikes St. Elisabeth untuk mendukung pelaksanaan pembelajaran secara online yaitu menggunakan pelayanan aplikasi Google Classroom, google meeting, zoom, dll (Enriquez, 2014; Sicat, 2015; Iftakhar, 2016), aplikasi seperti WhatsApp (So, 2016) dan media social Facebook dan Instagram (Kumar \& Nanda, 2018). Salah satu dampak positif dari penggunaan media pembelajaran daring adalah dosen dan mahasiswa menjadi familiar dengan penggunaan teknologi informasi melalui media digital seperti komputer, laptop, smartphone dll.

Namun demikian masih terdapat kendala-kendala yang muncul sebagai akibat dari dilaksanakannya pembelajaran online di masa pandemi ini. Ada banyak persiapan yang harus dilakukan dosen dan mahasiswa dalam melakukan pembelajaran daring termasuk kesiapanan dosen dan mahasiswa dalam mengoperasikan media pembelajaran daring walaupun pengoperasian media pembelajaran online tersebut belum optimal. Selain itu, penggunaan media pembelajaran daring tersebut menuntut dosen lebih berpikir kreatif dalam kegiatan pembelajaran untuk mampu menguasai teknologi dan mengoperasikan media belajar secara jaringan (daring), dan menuntut mahasiswa mengeluarkan biaya yang lebih banyak untuk membeli pulsa internet dari perubahan kebiasaan belajar mahasiswa sebelumnya. Sehingga pada masa pandemi ini, peran jaringan internet dalam pembelajaran daring sangat diandalkan untuk kelancaran proses pembelajaran daring.

Untuk mengatasi kendala tersebut maka Stikes St. Elisabeth perlu melakukan evaluasi untuk menilai kepuasaan mahasiswa terhadap pembelajaran daring saat masa pandemi ini. Penilaian kepuasan mahasiswa menjadi hal penentu mutu pembelajaran daring. Tingkat kepuasan mahasiswa dapat dianggap sebagai pembuktian bahwa sebagian besar mahasiswa dapat mengikuti pembelajaran daring secara nyaman, tetapi ada sebagian besar mahasiswa yang belum mampu beradaptasi dengan pembelajaran daring. Semakin tinggi tingkat kepuasan mahasiswa sebagai pengguna maka pembelajaran daring tersebut menjadi bermutu tinggi.

Kotler dan Keller dalam Mulyapradana et al. (2020) menyatakan bahwa kepuasan merupakan persepsi yang dirasakan seseorang mengenai rasa senang atau kecewa sebagai akibat membandingkan kinerja yang merupakan hasil (produk) terhadap ekspektasinya. Asmuji (2012) menyatakan bahwa kepuasan merupakan suatu kondisi yang dirasakan seseorang terhadap rasa senang atau kecewa setelah membandingkan persepsi kinerja hasil dan harapan-harapannya. Hal tersebut sependapat dengan pernyataan M.N Nasution (Mulyapradana, 2017) bahwa kepuasan merupakan tingkat perasaan seseorang setelah membandingkan kinerja atau hasil yang ia rasakan dengan harapannya. Menurut Mulyapradana et al., (2020) terdapat 3 faktor untuk mengukur tingkat kepuasan yaitu: kesesuaian kualitas pelayanan dengan tingkat harapan, tingkat kepuasan dibandingkan dengan sejenis, dan tidak ada keluhan yang dilayangkan, sedangkan Darmadi, 2000) menyatakan bahwa dimensi dari kepuasan terdiri atas 1. Sesuai yang diinginkan, 2. Mendapatkan yang diinginkan, 3. Kepuasan menyeluruh. Jadi kepuasan mahasiswa adalah nilai hasil perbandingan antara tingkat kenyataan dengan tingkat harapannya dalam menerima atau mendapatkan pelayanan yang diberikan oleh dosen kepada mahasiswa pada sebuah perguruan tinggi. 
Berdasarkan uraian tentang kendala pembelajaran secara daring dan tingkat kepuasaan mahasiswa di masa covid-19 maka peneliti tertarik untuk mengukur tingkat kepuasaan mahasiswa Stikes St. Elisabeth terhadap pembelajaran daring selama masa pandemik Covid-19. Adapun tujuan penelitian ini untuk mengetahui tingkat kepuasaan mahasiswa terhadap pembelajaran daring di Stikes St. Elisabeth. Penelitian terkait hasil kepuasaan mahasiswa terhadap pembelajaran daring diharapkan dapat menjadi acuan untuk melakukan perbaikan pembelajaran daring atau online bagi dosen Stikes St. Elisabeth.

\section{METODE}

Penelitian ini menggunakan pendekatan analisis deskripsi kuantitatif untuk mengolah data primer yang diperoleh. Populasi penelitian ini mahasiswa Program Studi DIII Keperawatan dari tingkat 1, 2 dan 3. Teknik Sampel menggunakan total sampling dengan analisis univariat pada mahasiswa yang sedang melaksanakan pembelajaran daring pada mata ajar Keperawatan dan Bahasa Inggris semester ganjil 2020/2021 di masa pandemi Covid-19. Data penelitian ini dari kuesioner diisi secara daring oleh mahasiswa. Instrumen penelitian ini diukur dengan skala Likert, untuk mengetahui pendapat, sikap, dan persepsi seseorang atau sekelompok orang mengenai suatu gejala atau fenomena (Djaali dalam Suwandi, E.,2019). Instrumen pengukuran tingkat kepuasan mahasiswa terdiri dari total 10 pernyataan dengan skala sangat puas, puas, kurang puas dan tidak puas.

Metode penelitian menggunakan metode observasi dilakukan dengan penyebaran angket kepuasan ke mahasiswa dan metode literature yaitu mencari literatur atau referensi dari buku, jurnal, internet maupun media lain yang relevan dengan tema penelitian ini. Metode pengumpulan data digunakan angket kepuasan mahasiswa terhadap proses belajar daring kepada 55 mahasiswa, yang dilakukan dengan cara pengisian angket oleh mahasiswa. Penyebaran angket ini dilaksanakan secara online menggunakan google form. Kemudian hasil data diolah, dianalisis dan disajikan dalam bentuk tabel untuk mengetahui kecenderungan kepuasan mahasiswa Stikes St. Elisabeth terhadap pembelajaran daring.

\section{HASIL DAN PEMBAHASAN}

Penelitian ini untuk mendiskripsikan kepuasan mahasiswa selama prose belajar daring selama masa pandemic covid 19 , hasilnya sebagai berikut :

Tabel 1.

Karakteristik Responden Menurut Jenis Kelamin ( $\mathrm{n}=55)$

\begin{tabular}{lcc}
\hline \multicolumn{1}{c}{ Jenis Kelamin } & $\mathrm{f}$ & $\%$ \\
\hline Laki-laki & 6 & 10.9 \\
\hline Perempuan & 49 & 89.1 \\
\hline
\end{tabular}

Tabel 1 dapat disimpulkan bahwa jumlah mahasiwa perempuan lebih banyak dibandingkan lakilaki. Tabel 2 memperlihatkan bahwa tingkat pemahaman mahasiswa terhadap materi perkuliahan daring selama pandemi Covid 19, bahwa mahasiswa yang kurang puas sebanyak $30(54,5 \%)$ dan mahasiswa yang puas sebanyak 19 (34,5\%). Berdasarkan tingkat kepuasan terhadap penyampaian materi perkuliahan selama pademi Covid 19 di STIKes St. Elisabeth, bahwa mahasiswa yang kurang puas sebanyak $32(58,2 \%)$ dan mahasiswa yang puas sebanyak $18(32,75 \%)$. 
Tabel 2.

Tingkat Kepuasan Mahasiswa

\begin{tabular}{|c|c|c|c|c|c|c|c|c|c|c|}
\hline \multirow[t]{2}{*}{ Isi Kuisioner } & \multicolumn{2}{|c|}{$\begin{array}{l}\text { Tidak } \\
\text { Puas }\end{array}$} & \multicolumn{2}{|c|}{$\begin{array}{l}\text { Kurang } \\
\text { Puas }\end{array}$} & \multicolumn{2}{|c|}{ Puas } & \multicolumn{2}{|c|}{$\begin{array}{l}\text { Sangat } \\
\text { Puas }\end{array}$} & \multicolumn{2}{|c|}{ Jumlah } \\
\hline & $\mathrm{f}$ & $\%$ & $\mathrm{f}$ & $\%$ & $\mathrm{f}$ & $\%$ & $\mathrm{f}$ & $\%$ & $\mathrm{f}$ & $\%$ \\
\hline Pemahaman materi perkuliahan d & 5 & 9,1 & 30 & 54,5 & 19 & 34,5 & 1 & 1,8 & 55 & 100 \\
\hline Penyampaian materi perkuliahan & 4 & 7,3 & 32 & 58,2 & 18 & 32,7 & 1 & 1,8 & 55 & 100 \\
\hline Metode pembelajaran daring & 10 & 18,2 & 26 & 47,3 & 18 & 32,7 & 1 & 1,8 & 55 & 100 \\
\hline Penggunaan media pembelajaran & 7 & 12,7 & 24 & 43,6 & 23 & 41,8 & 1 & 1,8 & 55 & 100 \\
\hline Komunikasi dua arah yang baik & 4 & 7,3 & 25 & 45,5 & 25 & 45,5 & 1 & 1,8 & 55 & 100 \\
\hline Kemudahan akses umpa & 3 & 5,5 & 25 & 45,5 & 26 & 47,3 & 1 & 1,8 & 55 & 100 \\
\hline Kelancaran jaringan saat perkuliahan daring & 20 & 36,4 & 23 & 41,8 & 12 & 21,8 & 0 & 0 & 55 & 100 \\
\hline $\begin{array}{l}\text { Peran dosen dalam membantu mahasiswa saat } \\
\text { perkuliahan daring }\end{array}$ & 3 & 5,5 & 16 & 29,1 & 35 & 63,6 & 1 & 1,8 & 55 & 100 \\
\hline Evaluasi pembelajaran daring & 3 & 5,5 & 20 & 36,4 & 31 & 56,4 & 1 & 1,8 & 55 & 100 \\
\hline $\begin{array}{l}\text { Perolehan hasil penilaian evaluasi pembelajaran } \\
\text { daring }\end{array}$ & 4 & 7,3 & 27 & 49,1 & 23 & 41,8 & 1 & 1,8 & 55 & 100 \\
\hline
\end{tabular}

Berdasarkan tingkat kepuasan mahasiswa STIKes St. Elisabeth terhadap metode belajar daring menunjukkan bahwa mahasiswa yang tidak puas sebanyak $10(18,2 \%)$, mahasiswa yang kurang puas sebanyak $26(47,3 \%)$ dan mahasiswa yang puas sebanyak 18 (32,75\%). Berdasarkan tingkat kepuasan mahasiswa STIKes St. Elisabeth terhadap penggunaan media pembelajaran daring, bahwa mahasiswa yang tidak puas sebanyak 7 (12,7\%), mahasiswa yang kurang puas sebanyak $24(43,6 \%)$ dan mahasiswa yang puas sebanyak $23(41,8 \%)$.

Berdasarkan tingkat kepuasan terhadap komunikasi dua arah atau timbal balik yang baik saat pademi Covid 19, bahwa mahasiswa yang tidak puas sebanyak $4(7,3 \%)$, mahasiswa yang kurang puas sebanyak $25(45,5 \%)$ dan mahasiswa yang puas sebanyak 25 (45,5\%). Berdasarkan tingkat kepuasan terhadap kemudahan akses umpan balik atas materi saat pademi Covid 19, bahwa mahasiswa yang kurang puas sebanyak sebanyak 25 (45,5\%) dan mahasiswa yang puas sebanyak $26(47,3 \%)$.

Berdasarkan tingkat kepuasan terhadap kelancaran jaringan saat perkuliahan daring pademi Covid-19, bahwa mahasiswa STIKes St. Elisabeth yang tidak puas sebanyak $30(36,4 \%)$, mahasiswa yang kurang puas sebanyak 23 (41,8\%) dan mahasiswa yang puas sebanyak $12(21,8 \%)$. Berdasarkan tingkat kepuasan terhadap peran dosen STIKes St. Elisabeth dalam membantu mahasiswa saat perkuliahan daring saat pademi Covid-19 mahasiswa yang tidak puas sebanyak $30(36,4 \%)$, mahasiswa yang kurang puas sebanyak 20 (36,4\%) dan mahasiswa yang puas sebanyak $31(56,4 \%)$.

Berdasarkan tingkat kepuasan terhadap evaluasi proses pembelajaran daring saat Covid-19 bahwa mahasiswa STIKes St. Elisabeth yang tidak puas sebanyak $30(36,4 \%)$, mahasiswa yang kurang puas sebanyak $16(29,1 \%)$ dan mahasiswa yang puas sebanyak $35(63,6 \%)$. Berdasarkan tingkat kepuasan terhadap perolehan hasil penilaian dari evaluasi proses belajar daring saat pademi Covid-19, bahwa mahasiswa STIKes St. Elisabeth yang tidak puas sebanyak 4 (7,3\%), mahasiswa yang kurang puas sebanyak $27(49,1 \%)$ dan mahasiswa yang puas sebanyak $23(41,8 \%)$.

Berdasarkan hasil penelitian ini, bahwa tingkat kepuasan pemahaman mahasiswa terhadap materi perkuliahan sebesar 54,5\% kurang puas. Menurut analisis peneliti, bahwa hasil penelitian ini juga selaras dengan jawaban mahasiswa bahwa 58,2\% kurang puas terhadap penyampaian materi perkuliahan yang disamaikan oleh dosen. Ini berarti masih diperlukan inovasi, yang harus dilakukan oleh dosen supaya penyampaian materi menjadi mudah dipahami oleh mahasiswa. Dosen harus merancang media belajar online yang lebih menarik dan berinovasi sebagai bentuk pemanfaatan media online serta memastikan kegiatan pembelajaran tetap berjalan, meskipun mahasiswa berada di rumah. 
Hal ini sesuai surat edaran Kemendikbud Nomor 4 Tahun 2020 tentang kebijakan pendidikan dalam pelaksanaan masa darurat penyebaran Covid-19 (https://covid19.hukumonline.com). Materi kuliah atau bahan pembelajaran disajikan secara online, yang memudahkan mahasiswa mengakses bahan ajar yang dibutuhkan secara cepat.

Bedasarkan penelitian ini, bahwa tingkat kepuasan terhadap metode pembelajaran daring, mahasiswa yang tidak puas sebesar 18,2\% dan kurang puas sebesar 47,3\%, sehingga mayoritas mahasiswa belum puas terhadap metoda pembelajaran daring. Ini juga selaras dengan hasil data terhadap penggunaan media pembelajaran daring, bahwa mahasiwa yang tidak puas sebesar $12,7 \%$, yang kurang puas sebesar 43,6\%. Kondisi ini berarti bahwa antara metode dan penggunaan media pembelajaran secara daring belum memberikan kepuasan bagi mahasiswa. Hal ini berkaitan dengan tingkat kesiapan dosen dan mahasiswa dalam adaptasi pembelajaran secara daring belum optimal, termasuk penggunaan metode dan media pembelajaran daring. Pembelajaran daring berarti proses belajar mengajar dilakukan secara online, yang didukung dengan aplikasi belajar online dan jejaring sosial (Pratama \& Mulyati, 2020). Pembelajaran daring dilakukan tanpa melakukan tatap muka di kelas, hanya dilakukan dengan jaringan internet.

Berdasarkan hasil penelitian ini, bahwa terdapat komunikasi dua arah yang kurang baik karena mahasiswa yang merasa tidak puas sebesar 7,3\% dan kurang puas dan yang merasa puas sama besar yaitu 45,5\%. Hal ini juga menunjukkan hasil data yang sama bahwa kemudahan akses umpan balik atas materi, mahasiswa yang kurang puas dan puas sama besar yaitu 45,5\%. Menurut analisis peneliti menunjukkan bahwa komunikasi timbal balik atau interaksi daring mahasiswa dan dosen tidak berjalan dengan baik, demikian juga mahasiswa mengalami kesulitan mengakses umpan balik materi dari dosen dan mahasiswa. Pembelajaran secara daring tidak terlepas dari peran jaringan internet. Jika jaringan internet lambat atau tidak stabil maka koneksi jaringan menjadi kendala bagi mahasiswa, sehingga sulit untuk mengakses internet, apalagi bagi mahasiswa yang bertempat tinggal di daerah pedesaan atau terpencil. Bahkan bagi mahasiswa yang menggunakan telepon seluler, karena letak georgrafis terisolasi, terpencil menyebabkan tidak ada jaringan atau bahkan jaringan yang tidak stabil.

Berdasarkan hasil penelitian ini, bahwa mahasiswa 36,4\% tidak puas, 41,8\% kurang puas dan yang puas hanya 21,8\% terhadap kelancaran jaringan saat perkuliahan daring, sementara mahasiwa yang kurang puas terhadap peran dosen dalam membantu mahasiswa saat perkuliahan daring, sebagian besar $63,6 \%$ sudah merasa puas dan $29,1 \%$ kurang puas terhadap peran dosen dalam membantu mahasiswa saat perkuliahan daring. Hal yang menjadi permasalahan bagi mahasiswa D3 Keperawatan yaitu kuota internet dimiliki mahasiswa kurang dan perkuliahan daring memerlukan waktu yang cukup lama, terutama bagi orangtua mahasiswa berpenghasilan rendah /kurang mampu. Pembelajaran daring sangat tergantung dari koneksi jaringan internet serta dimana letak geografis tempat tinggal mahasiswa juga berpengaruh terhadap akses dan kelancaran pembelajaran daring maupun peranan dosen dalam memberikan bantuan kepada mahasiswa saat perkuliahan daring. Komponen yang sangat penting perlu ditingkatkan dan diperbaiki dalami proses pembelajaran daring yaitu adanya jaringan internet yang stabil, dan komputer yang handal. Hasil penelitian ini, menunjukkan bahwa mahasiswa D3 merasa puas terhadap peran dosen dalam memberikan bantuan saat pembelajaran daring di STIKes St. Elisabeth. Dosen memberikan perhatian dan motivasi bagi mahasiswa yang mengalami kesulitan mengikuti pembelajaran daring.

Berdasarkan hasil penelitian ini, bahwa mahasiswa menilai puas dengan evaluasi pembelajaran daring sebesar $56,4 \%$, sedangkan yang puas terhadap perolehan hasil penilaian evaluasi pembelajaran daring sebesar 41,8\%. Masih ada 36,4\% yang kurang puas terhadap hasil evaluasi pembelajaran daring dan $49,1 \%$ kurang puas terhadap hasil penilaian evaluasi pembelajaran daring. Menurut analisis peneliti, bahwa mayoritas mahasiswa puas terhadap evaluasi pembelajaran daring, terbukti bahwa mahasiswa mengerjakan semua tugas dan ujian yang diberikan dosen dengan baik, sedangkan hasil penilaian evaluasi pembelajaran, mayoritas mahasiswa merasa kurang puas. Meskipun terdapat perbedaan antara tingkat kepuasan terhadap evaluasi pembelajaran dan hasil penilaiaan evaluasi 
pembelajaran dalam kondisi pandemi Covid-19, STIKes St. Elisabeth berupaya untuk tetap meningkatkan proses pembelajaran daring berjalan lancar dan mahasiswa tetap aktif mengikuti pembelajaran.

\section{SIMPULAN}

Tingkat kekurangpuasan mahasiswa terhadap pemahaman materi 54,5\%, terhadap penyampaian materi perkuliahan $58,2 \%$, terhadap metode pembelajaran daring $47,3 \%$, terhadap penggunaan media pembelajaran daring 43,6\%), terhadap komunikasi dua arah antara dosen dan kepuasan mahasiswa dan terhadap kemudahan akses umpan balik atas materi sebesar 45,5\%, terhadap kelancaran jaringan 41,8\%, dan terhadap perolehan hasil penilaian evaluasi pembelajaran daring di masa pademi Covid 19 $49,1 \%$. Sebagian besar mahasiswa merasa kurang puas terhadap pembelajaran daring yang dilakukan di Stikes St. Elisabeth Semarang. Dari data penelitian tersebut, perlu diadakan penelitian selanjutnya terkait perbaikan atau tindak lanjut dari hasil kepuasan mahasiswa dalam pembelajaran daring

\section{DAFTAR PUSTAKA}

Asmuji. (2012). Manajemen Keperawatan, 1st ed. Yogyakarta: Ar-Ruzz Media

Darmadi. (2000). Mari Bangkit Membangun Kepuasan Pelanggan. Swasembada. Vol. 16, No. 18.

Distance Learning Environments: Are They The Same? Internet and Higher Education. Vol. 14. Issue 2. https://doi.org/10.1016/j.iheduc.2010.10.001

Enriquez, M. A. S. (2014). Students ' Perceptions on the Effectiveness of the Use of Edmodo as a Supplementary Tool for Learning. DLSU Research Congress. https://doi.org/10.1017/CBO9781107415324.004

Fadli, Rizal. (2020). Corona virus. Diakses dari https://www.halodoc.com/kesehatan/coronavirus pada tanggal 11 Juni 2020

Fey.CNN Indonesia. (n.d.-b).65 Kampus Kuliah Dari Rumah, Sultan Yogya Ragukan Efektivitas.Retrieved from https://www.cnnindonesia.com/nasional/20200316110707-20$\underline{\text { 483756/65-kampus-kuliah-dari-rumah-sultan-yogya-ragukan-efektivitas. diakses pada Juni } 2020 .}$

Gikas, J., \& Grant, M. M. (2013). Mobile Computing Devices In Higher Education: Student Perspectives on Learning with Cellphones, Smartphones \& Social Media. Internet and Higher Education. https://doi.org/10.1016/j.iheduc.2013.06.002

Hanum, N. S. (2013). Keefetifan e-learning sebagai media pembelajaran (studi evaluasi model pembelajaran e-learning SMK Telkom Sandhy Putra Purwokerto). Jurnal Pendidikan Vokasi. https://doi.org/10.21831/jpv.v3i1.1584

Harnani, S. (2020). Effektivitas Pembelajaran Daring di masa Pandemi Covid-19. https://bdkjakarta.kemenag.go.id/berita/efektivitas-pembelajaran-daring-di-masa-pandemi-covid19. diakses tanggal 17 September 2020

Iftakhar, S. (2016). GOOGLE CLASSROOM: WHAT WORKS AND HOW?. Journal of Education and Social Sciences. Vol. 3.

Karwati, E. (2014). Pengaruh Pembelajaran elektronik (e-learning) terhadap Mutu Belajar Mahasiswa. Jurnal Penelitian Komunikasi. Vol. 17 No. 1. https://doi.org/10.20422/jpk.v17il.5 
Korucu, A. T., \& Alkan, A. (2011). Differences Between M-Learning (Mobile Learning) and ELearning, Basic Terminology and Usage Of M-Learning in Education. Procedia - Social and Behavioral Sciences. Vol. 15. https://doi.org/10.1016/j.sbspro.2011.04.029

Kumar, V., \& Nanda, P. (2018). Social Media in Higher Education. International Journal of Information and Communication Technology Education. https://doi.org/10.4018/ijicte.2019010107

Lestari, Selvy Windy. (2020). Kendala Pelaksanaan Pembelajaran Jarak Jauh (PJJ) Dalam Masa Pandemi Ditinjau Dari Media Pembelajaran. Jurnal Ilmu Pendidikan. Volume 2 No. 3.

Moore, J. L., Dickson-Deane, C., \& Galyen, K. (2011). E-Learning, Online Learning, and distance learning environments: Are they the same? Internet and Higher Education. https://doi.org/10.1016/j.iheduc.2010.10.001

Mulyapradana, A. (2017). Upaya Peningkatan Kepuasan Masyarakat Terhadap Pelayanan Pada Kantor Kecamatan Pekalongan Timur. Widya Cipta - Jurnal Sekretari Dan Manajemen. Vol 1. No 2. https://doi.org/10.31294/widyacipta.v1i2.1990.g1557

Mulyapradana, A., Anjarini, A. D., \& Harnoto, H. (2020). Pengaruh Kualitas Pelayanan Terhadap Kepuasan Pelanggan di PT. Tempo Cabang Tegal. Jesya (Jurnal Ekonomi \& Ekonomi Syariah). Vol 3. No 1. https://doi.org/10.36778/jesya.v3i1.115 -

Sicat, A. S. (2015). Enhancing College Students' Proficiency in Business Writing Via Schoology. International Journal of Education and Research. Vol. 3. No. 1

So, S. (2016). Mobile Instant Messaging Support For Teaching and Learning in Higher Education. Internet and Higher Education. https://doi.org/10.1016/j.iheduc.2016.06.001

Suni Astini, N. K. (2020). Tantangan Dan Peluang Pemanfaatan Teknologi Informasi Dalam Pembelajaran Online Masa Covid-19. Cetta: Jurnal Ilmu Pendidikan. Vol 3. No 2. https://doi.org/10.37329/cetta.v3i2.452

Surat Edaran Kementerian Pendidikan dan Kebudayaan (Kemendikbud) Direktorat Pendidikan Tinggi No. 1 Tahun 2020 dan surat edaran Kementerian Pendidikan dan Kebudayaan No. 4 tahun 2020. https://covid19.hukumonline.com. Diakses tanggal 17 Mei 2020

Suwandi, E, dkk. (2019). Analisis Tingkat Kepuasan Menggunakan Skala Likert Pada Layanan Speedy Yang Bermigrasi Ke Indihome. Jurnal Teknik Elektro Universitas Tanjungpura. Vol 1, No 1

Prasetya, T.A. \& Harjanto, C.T. (2020). Pengaruh Mutu Pembelajaran Online Dan Tingkat Kepuasan Mahasiswa Terhadap Hasil Belajar Saat Pandemi Covid19. Jurnal Pendidikan Teknologi dan Kejuruan. Vol. 17. No. 2. http://dx.doi.org/10.23887/jptk-undiksha.v17i2.25286

Pratama, R.E. \& Mulyati, S. (2020). Pembelajaran Daring dan Luring pada Masa Pandemi Covid-19. Gagasan Pendidikan Indonesia. Vol.1, No.2. http://dx.doi.org/10.30870/gpi.v1i2

Undang-Undang RI no. 6 tahun 2018 tentang Kekarantinaan Kesehatan. https://sipuu.setkab.go.id/PUUdoc/175564/UU\%20Nomor\%206\%20Tahun\%202018.pdf, tanggal 17 September 2020 